UDC 621.793

\title{
PECULIARITIES OF THE FORMATION OF A HARDENED LAYER DURING LASER BORINIZING OF PISTON RINGS
}

\author{
D.B. Hlushkova ${ }^{1}$, Y.V. Ryzhkov ${ }^{1}$, N.E. Kalinina ${ }^{2}$, T.V. Nosova ${ }^{2}$ \\ ${ }^{1}$ Kharkiv National Automobile and Highway University, Kharkiv, Ukraine \\ E-mail:diana@khadi.kharkov.ua; \\ ${ }^{2}$ Oles Honchar Dnipro National University, Dnipro, Ukraine \\ E-mail: kalinina.dnu@gmail.com
}

Insufficient wear resistance of piston ring materials often limits the growth of machine productivity and service life. The use of traditional drilling methods associated with the diffusion of boron into the solid phase will lead to the formation of a working layer with high fragility. Therefore, the problem of increasing the wear resistance of piston rings without embrittlement is relevant. The use of laser heating during drilling provides the formation of a new layer with special properties. However, optimal properties can only be achieved after the relationship between the process parameters and the depth of the bored layer has been established. The influence of laser heating parameters on the composition and depth of the drilling layer is established in the work. The results of research can be extended to other parts that are subject to intensive wear.

\section{INTRODUCTION}

One of the ways to improve the performance properties of piston rings made of cast irons that are subject to wear is boronizing. However, the use of traditional boronizing methods associated with the diffusion of boron into the solid phase leads to the formation of a working layer with high fragility. Therefore, the current problem is the development of another method of surface hardening, which does not lead to embrittlement. The implementation of such a process can be performed using laser heating with infusion of the surface layer. However, the use of this method can be offered to production process only after a detailed inspection of the relationship between the parameters of the process and the depth of the layer, as well as the inspection of the features of structure formation in specific conditions of laser boronizing.

The analysis of papers indicates that no methods have been developed for increasing the wear resistance of piston rings by boronizing, performed using modern technologies. Sources [1-3] propose an increase in durability either by traditional boronizing or laser treatment. However, there is no combination of these two technological processes.

The properties of the product, on which the boronated layer is applied, depend on the composition of the base metal, the power and power density of laser radiation, the constancy of the pulse, the speed of its movement over the surface of the product, the overlap of tracks (spots), and the depth of the layer [4-6].

The implementation of the laser boronizing process can be performed on the basis of establishing a relationship between the laser heating parameters and the depth of the boronated layer.

In paper [4], the phase composition, microstructure and microhardness of boronated layers obtained by laser infusion of boron-containing coatings on the surface of $45,40 \mathrm{X} 11 \mathrm{M} 3 \Phi$ and $12 \mathrm{X} 18 \mathrm{H} 10 \mathrm{~T}$ steels were investigated at a laser power density of $200 \mathrm{MW} / \mathrm{m}^{2}$ and a beam travel speed over the treated surface $0.05 \mathrm{~m} / \mathrm{s}$.
Such a mode led to the presence of infused boron particles in the thin surface layer after processing, which did not have time to react with the liquid metal. It is obvious that for the complete dissolution of boron particles, it is desirable either to change their dispersion or to increase the laser power density. The composition of the boronated layer depends on the grade of the treated steel; it contains $\alpha$ - and $\gamma$-solid solutions, $\mathrm{Fe}_{2} \mathrm{~B}$ boride, as well as complex carbides of various compositions. A significant increase in microhardness was noted, the magnitude and nature of which also depend on the steel grade.

In paper [5], 4 phases $\left(\alpha-\mathrm{Fe}, \mathrm{Fe}_{2} \mathrm{~B}, \mathrm{Fe}_{3} \mathrm{~B}, \mathrm{TiB}_{2}\right)$ were found in the composition of the coating obtained by laser boronizing. The authors consider the total time of exposure of radiation to the material during pulsed laser alloying to be the decisive factor determining the formation of a particular type of boride. They found that the amount of formed $\mathrm{Fe}_{2} \mathrm{~B}, \mathrm{Fe}_{3} \mathrm{~B}$ borides is much higher at a laser power density of $680 \mathrm{MW} / \mathrm{m}^{2}$ than at a laser power density of $800 \mathrm{MW} / \mathrm{m}^{2}$, but in order to obtain a higher microhardness, a degree of overlapping of at least $80 \%$ is desirable. However, the main focus of the paper is made on the types, conditions of occurrence and stability of borides in the alloyed layer. The purpose of this paper was to determine the optimal conditions for laser boronizing in order to strengthen specific parts. In addition, due to the difference in the methods of obtaining the metal and its initial structure, the conditions for the formation of the structure and properties of the boranated layer in the $\mathrm{Y} 12$ steel considered by the authors and in high-strength cast iron are significantly different.

V. Biriukov [6] believes that the main reasons for the brittleness and destruction of boride coatings are: the absence of wear-resistant secondary structures, high brittleness of iron borides, the presence of microcracks and pores in the boride layer. Boride particles separated from the surface layer, having a high microhardness, initiate the development of abrasive wear. For composite structures, the plasticity of which is many times higher than that of a continuous boride layer, abrasive 
wear is significantly lower due to the absence of chips and cracks in the surface layer in a wide range of sliding speeds, therefore, the author recommends boride coatings made of mixtures giving composite structures, followed by laser infusion.

The objective of this paper was to establish the influence of laser influence parameters on the depth of the boranated layer and to identify the features of the formation of the structure of such layers during hardening of parts of piston rings made of cast iron.

\section{MATERIAL AND EXPERIMENTAL METHOD}

The investigated material was high-strength cast iron containing $\mathrm{C}=3.47 \%, \mathrm{Si}=2.15 \%, \mathrm{Mn}=1.36 \%$. After pretreatment, it had a pearlite-ferrite structure (85...90\% of pearlite). The size of spheroidal graphite corresponds to 3 points. Microhardness of pearlite is $2280 \ldots 2410 \mathrm{MPa}$, ferrite - 2070..2280 MPa, average value over the metal matrix of the surface of the part 2280...2410 MPa.

Laser treatment was performed with a continuous $\mathrm{CO}_{2}$ laser. At a constant irradiation power of $0.6 \mathrm{~kW}$, the specimen displacement speed was varied in the range of $2 \ldots 4 \mathrm{~mm} / \mathrm{s}$. The thickness of the boron coating was 0.15 and $0.30 \mathrm{~mm}$. Conditional defocusing made it possible to change the diameter of the irradiation spot from 2 to $4 \mathrm{~mm}$. A mixture of amorphous boron with acetone and nitrocellulose lacquer was used as a backfill.

The structure, phase composition, and depth of the boronated layer were investigated by optical microscopy using conventional and decorating etching and X-ray diffraction analysis on a DRON-3 unit.

\section{RESEARCH RESULTS AND THEIR DISCUSSION}

The initial structure of cast iron is shown in Fig. 1.

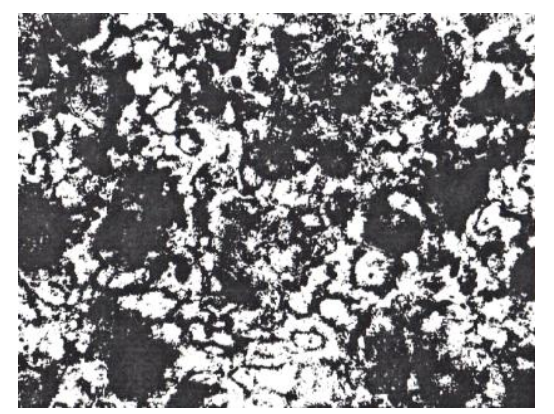

Fig. 1. The structure of the initial cast iron, decorating etching, $x 100$

In the investigated range of laser treatment modes in irradiated cast iron, layers are formed with the emergence of zones quenched from the molten state to the surface:

1 - layers with an infusion zone;

2 - layers with zones hardened from temperatures lower than the solidus temperature of the metal base (with a hardened zone) to the surface.

The infusion of the cast iron surface depends on the rate of irradiation. At the applied irradiation rates, it infused over the entire area of contact with the beam.
The hardening zone is located between the infused zone and the base metal.

It was found that the change in the metal structure as a result of alloying with boron occurs only in the infusion zone. The structure of the infusion zone in cast iron, in contrast to steels, contains 3 components: quenched from a molten mass of white cast iron, quenched from a molten mass of high-carbon steel, graphite (Figs. 2, 3). The structure is inhomogeneous, since the short duration of laser irradiation does not allow obtaining a homogeneous liquid solution in the infused layer. In addition, an essential role is played by the initial nonhomogenity of cast iron (see Fig. 1) and the laws of diffusion redistribution of the main elements in it during heating and cooling, these laws differs from the ones for steel.

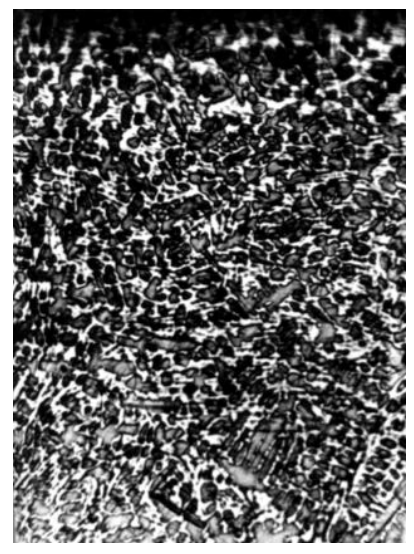

$a$

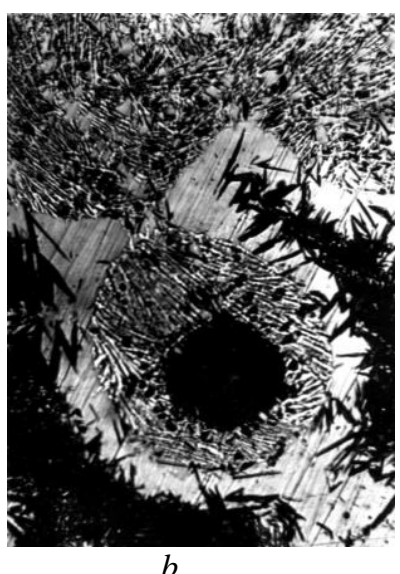

$b$
Fig. 2. Infusion zone. Structure of the white cast iron tempered from a melted mass: a-general view, x100; $b$-graphite inclusion, $x 500$

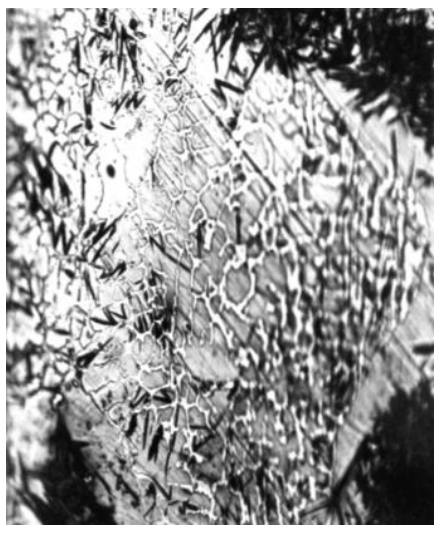

Fig. 3. Infusion zone. Structure of the high-carbon steel tempered from a melted mass, $x 500$

With a decrease in the irradiation rate, the proportion of areas with a high-carbon steel structure decreases. $\mathrm{X}$-ray analysis showed the presence of austenite, martensite and cement carbide in the infused zones. With a decrease in the irradiation rate, the amount of austenite and cement carbide increases.

The microhardness of the infusion zone is also inhomogeneous $8500 \ldots 9500 \mathrm{MPa}$ for quasi-eutectic structure, $\quad 4200 \ldots 5700 \mathrm{MPa}$ for austenite, $6300 \ldots 8500 \mathrm{MPa}$ for martensite-austenite structure. The rather high hardness of austenite is explained by its saturation with boron and, possibly, phase hardening dur- 
ing rapid crystallization. With a decrease in the irradiation rate, the microhardness of the martensite-austenite structure decreases, which is explained by an increase in the proportion of austenite and tempering of the martensite component.

In the quenching zone, depending on the heating temperature, needle-type or structureless martensite with a microhardness of $7300 \ldots 8500 \mathrm{MPa}$.

Fig. 4 shows the dependence of the depth of the boronated layer on the speed of movement of the specimen for two cases - with a backfill thickness of 0.15 and $0.30 \mathrm{~mm}$ (curves 2 and 1, respectively).

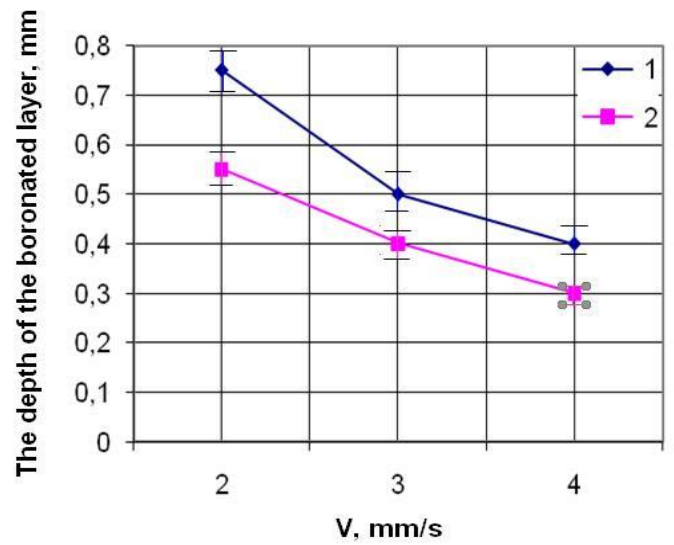

Fig. 4. Dependence of the depth of the boronated layer on the speed of movement of the specimen: 1 -backfill

thickness $0.3 \mathrm{~mm} ; 2$ - backfill thickness $0.15 \mathrm{~mm}$

It follows from the graph that with an increase in the speed of movement of the specimen, the depth of the boronated layer decreases. This dependence is observed both with a backfill thickness of $0.15 \mathrm{~mm}$ and with a thickness of $0.30 \mathrm{~mm}$. At all speed values of the sample movement for the used boron-containing mixture with the indicated thicknesses, the greater thickness of the boronated layer and the thermal impact zone corresponds to the greater thickness of the backfill.

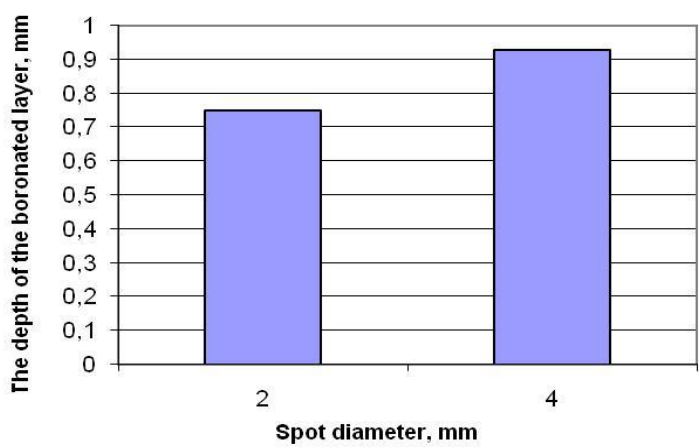

Fig. 5. Histogram of the depth of the boronated layer with a backfill thickness of $0.3 \mathrm{~mm}$ and a specimen movement speed of $2 \mathrm{~mm} / \mathrm{s}$ for a different spot diameter

Fig. 5 shows a histogram of the depth of the boronated layer with a backfill thickness of $0.3 \mathrm{~mm}$ and a specimen movement speed of $2 \mathrm{~mm} / \mathrm{s}$ for a spot diameter of 2 and $4 \mathrm{~mm}$, and Fig. 6 - the same histogram in the case of a movement speed of $4 \mathrm{~mm} / \mathrm{s}$.

It follows from the presented histograms that varying of the conditional defocusing, which results in a change in the diameter of the irradiation spot, leads to a noticeable change in the depth of the laser alloying layer. Thus, a decrease in defocusing while all other conditions being equal, resulting in a decrease in the spot diameter, causes a decrease in the depth of laser irradiation.

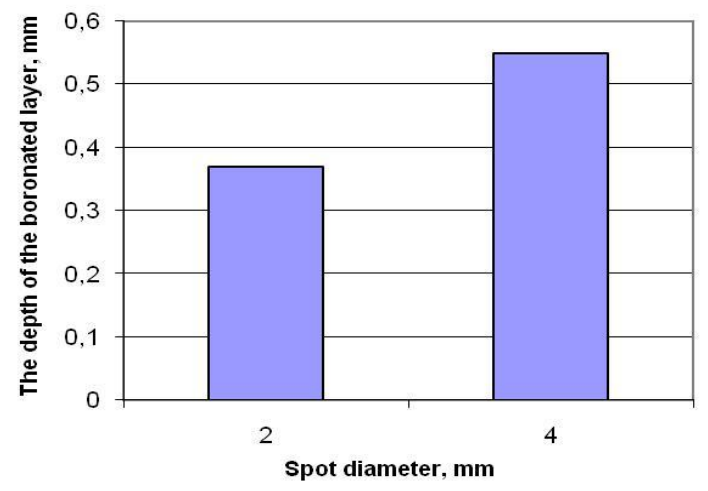

Fig. 6. Histogram of the depth of the boronated layer with a backfill thickness of $0.3 \mathrm{~mm}$ and a specimen movement speed of $4 \mathrm{~mm} / \mathrm{s}$ for a different spot diameter

It can be assumed that the effect obtained is due to a significant increase in the surface temperature, which caused intense evaporation of the backfill layer and an increase in energy consumption for evaporation [7].

In addition, with less defocusing, the total area of overlapping pulses noticeably increases, therefore more energy is spent on re-infusion of the metal and the diffusion processes occurring at the same time, the direction of which can change cyclically when the surface is heated and cooled. The processes of creating new phases, introducing boron into austenite, cement carbide, martensite can also change cyclically, which also requires energy consumption. The study of the profile of the boundary of the infusion zone shows that it has a wavy character, which confirms the presence of areas of overlapping impulses.

As shown in other papers of the authors [8], the boronated layer in high-strength cast iron contains such phases as $\mathrm{FeB}, \mathrm{Fe}_{2} \mathrm{~B}$, $\alpha$-phase, boroncementite $\mathrm{Fe}_{3}(\mathrm{~B}, \mathrm{C})$ (Fig. 7). Comparison of the data of microscopic and $\mathrm{X}$-ray structural analyzes with the phase diagrams of $\mathrm{Fe}$ $\mathrm{B}$ and $\mathrm{Fe}-\mathrm{Fe}_{2} \mathrm{~B}-\mathrm{Fe}_{3} \mathrm{C}$ made it possible to establish that these phases during the crystallization of the melted mass can form various structural components throughout the volume of the infused layer: a mixture of the peritectic type $\left(\mathrm{FeB}+\mathrm{Fe}_{2} \mathrm{~B}\right)$, hypereutectic, eutectic and hypoeutectic structures.

Differentiation of phases in various structures was performed by the method of decorating etching, by analyzing the shape of the primary crystals.

The excess $\alpha$-phase is formed from the primary crystals of the $\gamma$-phase according to the martensitic mechanism. Boroncementite $\mathrm{Fe}_{3}(\mathrm{~B}, \mathrm{C})$ and borides $\mathrm{FeB}, \mathrm{Fe}_{2} \mathrm{~B}$ differ according to metallographic inspection - in the form of excess crystals and behavior during decorating etching. Primary crystals of boroncementite are lamellar formations - flat dendrites, which are revealed in the form of thin stripes in sections perpendicular to the surfaces.

In accordance with the triple diagram, boroncementite can be formed not only by direct crystallization from a liquid solution, but also as a result of peritectic transformation [2]. 


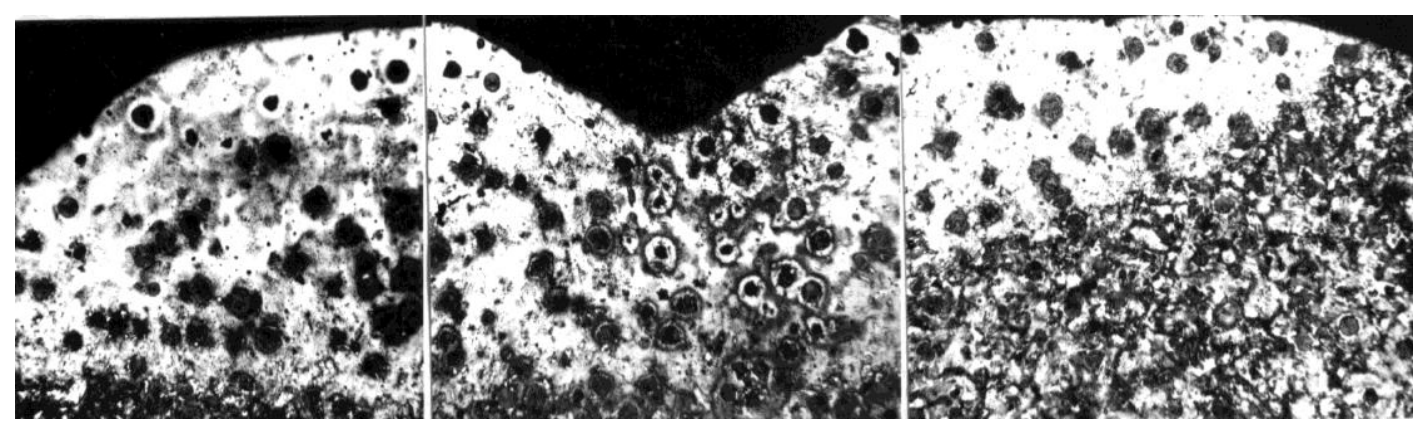

Fig. 7. Piston ring profile after laser boronizing

Structurally free crystals of $\mathrm{Fe}_{2} \mathrm{~B}$ borides are observed in the form of rod crystals having the shape of squares, rhombuses, triangles in cross-section, i.e. of all possible sections of the tetragonal prism. The eutectic constituents of the structures in the boronated layer are characterized by a certain variety of structure, dispersion, and quantitative relationship between the phases.

Comparison of layer structures with comparable depths illustrates the effect of backfill thickness on the structure. For example, a three-zone layer with a predominance of eutectic and hypoeutectic structures can become two-zone with a hypereutectic and eutectic zone and with a predominance of the first when the thickness of the backfill changes from 0.3 to $0.15 \mathrm{~mm}$.

With an increase in the irradiation rate while other processing conditions being equal, the depth of the layer decreases, i.e. the volume of the molten metal bath decreases, and, consequently, the amount of boron dissolved in it increases. X-ray diffraction and microscopic analysis data record changes in the composition of the layer. X-ray diffraction analysis is manifested in an increase in the intensity of boroncementite lines with an increase in the irradiation rate, and microstructurally, in an increase in the proportion of high-boron structures.

Thus, it was found that laser boronating with an infusion rate of $3.5 \ldots 4.0 \mathrm{~mm} / \mathrm{s}$ at a power of $0.6 \mathrm{~kW}$ significantly increases the microhardness of the piston ring surface and can be recommended for practical use.

\section{CONCLUSIONS}

1. It was confirmed that during laser boronation with an increase in the speed of specimen movement, the depth of the boronated layer decreases.

2. An increase in the depth of the borobated layer is observed with an increase in the diameter of the irradiation spot from 2 to $4 \mathrm{~mm}$. It can be assumed that the effect obtained is due to either the intense evaporation of the backfill layer, or an increase in the total area of overlapping pulses, and the corresponding additional energy consumption.

3. X-ray and metallographic analysis revealed the phases and structural components of the boronated layer.

4. Microhardness of the infusion zone is inhomogeneous: $8500 \ldots 9500 \mathrm{MPa}$ for quasi-eutectic structure, $4200 \ldots 5700 \mathrm{MPa}$ for austenite, $6300 \ldots 8500 \mathrm{MPa}$ for martensite-austenite structure. The rather high hardness of austenite is explained by its saturation with boron and, possibly, phase hardening during rapid crystallization.

5. In the quenching zone, depending on the heating temperature, needle-type or structureless martensite with a microhardness of $7300 \ldots 8500 \mathrm{MPa}$ is formed.

6 . As a result of the research performed for hardening the piston rings, the infusion rate of $3.5 \ldots 4.0 \mathrm{~mm} / \mathrm{s}$ at a power of $0.6 \mathrm{~kW}$ can be recommended.

\section{REFERENCES}

1. I.P. Gladkiy, V.I. Mosch'enok, V.P. Tarabanova, N.A. Lalazarova, D.B. Glushkova. Tehnologiya konstrukcionnyh materialov $i$ materialovedenie. H.: HNADU, 2014, 464 p (in Russian).

2. A.G. Grigor'yanc. Osnovy lazernoy obrabotki materialov. M.: "Mashinostroenie", 2009, 272 p. (in Russian).

3. D. Hlushkova, D. Leontiev, O. Voronkov, V. Korohodskyi, et al. Mathematical modeling of operating processes in the pneumatic engine of the car I SAE Technical Paper 2020-01-2222. 2020.

4. A.B. Ly'senko, N.N. Kozina, T.V. Gulyaeva, V.V. Shibaev. Struktura i svoystva staley posle borirovaniya s ispol'zovaniem lazernogo nagreva // Metallovedenie i termicheskaya obrabotka, 1991, N 3, p. 25 (in Russian)

5. V.V. Girjon, T.A. Mal'ceva. Lazernoe legirovanie stali U12 boridom titana $\mathrm{TiB}_{2} / /$ Metallofizika $i$ noveyshie tehnologii. 2006, N 10, p. 1383-1396 (in Russian).

6. V.P. Biryukov, M.G. Krukovich, S.N. Il'in, N.P. Klochkov. Lazernaya obrabotka boridny'h sloev. Resursosberegayusch'ie tehnologii remonta, vosstanovleniya $i$ uprochneniya detaley mashin: Materialy MNPK. SPb.: "Izd-vo Politehn". Un-ta, 2010 (in Russian).

7. D.B. Hlushkova, O.D. Hrinchenko, L.L. Kostina, A.P. Cholodov. The choice of material for strengthening of leading edges of working blades of steam turbines // Problems of Atomic Science and Technology. 2018, N 1(113), p. 181-188.

8. D.B. Glushkova. Nauchnye i tehnologicheskie osnovy poverhnostnogo uprochneniya nagrujennyh detaley stroitelnogo oborudovaniya dlya povysheniya ih dolgovechnosti: dis. ... doctor techn.nauk.: 05.02.01. Dnepropetrovsk, 2016, 330 p. (in Russian).

Article received 24.11.2021 


\section{ОСОБЕННОСТИ ФОРМИРОВАНИЯ УПРОЧНЕННОГО СЛОЯ ПРИ ЛАЗЕРНОМ БОРИРОВАНИИ ПОРШНЕВЫХ КОЛЕЦ}

\section{Д.Б. Глуикова, Ю.В. Рыюков, Н.Е. Калинина, Т.В. Носова}

Недостаточная износостойкость материалов поршневых колец часто ограничивает рост производительности машин и срока их эксплуатации. Использование традиционных способов борирования, связанных с диффузией бора в твердую фазу, приведет к формированию рабочего слоя, обладающего высокой хрупкостью. Поэтому актуальна проблема повышения износостойкости поршневых колец без охрупчивания. Использование лазерного нагрева при борировании обеспечивает образование нового слоя с особыми свойствами. Однако оптимальные свойства могут быть достигнуты только после установления связи между параметрами проведения процесса и глубиной борированного слоя. В работе установлено влияние параметров лазерного нагрева на состав и глубину борированного слоя. Результаты исследований могут быть распространены и на другие детали, подлежащие интенсивному износу.

\section{ОСОБЛИВОСТІ ФОРМУВАННЯ ЗМІЦНЕНОГО ШАРУ ПРИ ЛАЗЕРНОМУ БОРУВАННІ ПОРШНЕВИХ КІЛЕЦЬ}

\section{Д.Б. Глушкова, Ю.В. Рижкков, Н.С. Калініна, Т.В. Носова}

Недостатня зносостійкість матеріалів поршневих кілець часто обмежує зростання продуктивності машин і терміну їх експлуатації. Використання традиційних способів борування, пов'язаних з дифузією бору в тверду фазу, приведе до формування робочого шару, що має високу крихкість. Тому актуальною є проблема підвищення зносостійкості поршневих кілець без окрихчування. Використання лазерного нагріву при боруванні забезпечує утворення нового шару з особливими властивостями. Однак оптимальні властивості можуть бути досягнуті тільки після встановлення зв’язку між параметрами проведення процесу і глибиною борованого шару. В роботі встановлено вплив параметрів лазерного нагріву на склад та глибину шару борування. Результати досліджень можуть бути поширені і на інші деталі, що підлягають інтенсивному зношуванню. 